\title{
Læreruddannelsens andenordensdidaktik
}

\author{
Thomas Iskov, Docent, ph.d., Center for uddannelseskvalitet, \\ professionspolicy og praksis, VIA University College, tisk@via.dk
}

\begin{abstract}
Resumé
Det særlige ved at undervise på en læreruddannelse er, at man underviser nogen, der selv skal lære at undervise. Dette giver anledning til et dobbelt didaktisk blik fra læreruddanneren eller udvikling af en andenordensdidaktik. Med afsæt i denne konstatering i læreruddannelsesforskningen, søger artiklen at besvare spørgsmålet om, hvordan denne andenordensdidaktik kan operationaliseres og udmønte sig i den didaktiske praksis på læreruddannelsen.

Som svar på dette spørgsmål udvikles en andenordensdidaktisk planlægnings- og analysemodel med afsæt $\mathrm{i}$ en almen didaktisk model orienteret mod folkeskolen. Modellen følges op af anbefalinger om 'modelling' som eksemplarisk undervisning $\mathrm{i}$ tre forskellige betydninger, der kan bidrage til didaktikken og undervisningen på læreruddannelsen.
\end{abstract}

Nøgleord: Læreruddannelsesdidaktik, andenordensdidaktik, modelling, læreruddannelse, dobbelt didaktik

\begin{abstract}
What is characteristic for teacher education, is that those who are taught must learn to teach themselves. This leads to a dual didactic perspective and development of a second-order pedagogy. Based on teacher education research, the article seeks to answer the question of how such second-order pedagogy can be operationalized in didactic practice.

The article generates a model for second-order planning and analysis based on a general pedagogical model oriented towards primary school. The model is followed by recommendations on modelling as exemplary teaching in three different senses that can contribute to the pedagogy, didactics and teaching in teacher education.
\end{abstract}

Keywords: Explicit modelling, second order teaching, teacher education, reflective practice, exemplary teaching

\section{Indledning}

I et oplæg på en fælles dag for alle læreruddannere i Danmark (Fælles vidensdag d. 27. feb. 2019) påpeger den norske professor Elaine Munthe, at der er behov for at identificere og udvikle 'kernekompetencen' for at kunne kva- 
lificere undervisningen på læreruddannelsen - og i forlængelse heraf kvalificere undervisningen i skolen. Hun refererer til den særlige kompetence, der kræves for at undervise nogen, der skal lære at undervise. Forskningen i læreruddannelsens andenordensdidaktik konstaterer da også, at der mangler viden herom (Oettingen \& Jensen, 2017; Lunenberg et al., 2007; Goodwin et al., 2014), og det er på denne baggrund, at Lunenberg et al. (2007) efterspørger en kvalificering af læreruddanneres kompetence til at modellere og eksplicitere egen undervisning og at forbinde deres undervisning til teori:

\section{On the basis of the literature search and our exploratory study, there appears to be little or no recognition of modelling as a teaching method in teacher education. The findings of our study confirm the problems cited in the literature, namely that teacher educators apparently lack the knowledge and skills needed to use modelling in a productive way, to make their own teaching explicit, and to rethink the connection between their teacher education practices and public theory. (Lunenberg et al., 2007, s. 590)}

Denne artikel afdækker det omtalte videnshul yderligere, med den ambition at præcisere behovet for viden om andenordensdidaktik og besvare forskningsspørgsmålet om, hoordan man kan bidrage med andenordensdidaktiske refleksioner $i$ forhold til det særlige aspekt i læreruddannelsesdidaktik, som handler om at se, koble og tydeliggøre undervisningen på læreruddannelsen $i$ sammenhæng med undervisningens planlægning, gennemførelse og udvikling $i$ skolens arena.

Det første afsnit udgør en state of the art (Grant \& Booth, 2009) for det afgrænsede felt, der har med andenordensdidaktik (second order teaching) og modelling i læreruddannelse at gøre. Fælles for den fremsøgte forskning er, at den angiver andenordensdidaktikken som underbelyst, og kun få artikler udfolder en konkretisering heraf gennem begrebet modelling, overordnet forstået som en synliggørelse af undervisernes didaktiske valg. (Den engelske betegnelse anvendes artiklen igennem for at undgå forveksling med modelleringsbegrebet, som det bl.a. anvendes i matematik og naturfag om det at omsætte i modeller).

Med dette afsæt undersøges og diskuteres modelling i flere betydninger som et muligt svar på den andenordensdidaktiske efterspørgsel. Hensigten er at præcisere, hvori modelling konkret kan bestå, og udvikle viden om, hvordan didaktikken på læreruddannelsen kan synliggøre relationen mellem uddannelse og profession, teori og praksis, således at undervisningen på 
uddannelsen opleves som meningsfuld af de studerende. Hensigten er derudover at medgive viden om modelling, som læreruddannere kan omsætte $i$ en undervisning, der sigter mod velbegrundet og afstemt undervisning $i$ fremtidige læreres didaktiske praksis.

Med dette ærinde in mente skiftes perspektiv til skolens arena, og en almen didaktik for lærerne udfoldes via en model, hvis systematik og ordning af de centrale didaktiske kategorier i begrundelses-, betingelses- og beslutningsmomenter hævdes at være almen og gældende for såvel grundskolen som læreruddannelsen. Præmissen er, at læreruddanneren må være bevidst om skolens og lærerens didaktik for at kunne eksplicitere, hvordan undervisningen på læreruddannelsen står i relation hertil.

Artiklens sigte er dermed udvikling af en andenordensdidaktik, som indebærer et dobbelt blik på læreruddannelse og skole. Dette blik fordrer refleksivitet $\mathrm{i}$ forholdet mellem didaktik og undervisning i de to arenaer, og som en støtte hertil indlejres den almen didaktiske model for skolen i en tilsvarende læreruddannelsesdidaktisk model. Denne formidles som en planlægningsog analysemodel, der kan bidrage til at reflektere andenordensperspektivet.

I forlængelse af modellen og begrebet om modelling udfoldes eksemplarisk undervisning i tre udgaver i slutningen af artiklen, hvor den sidste indebærer eksplicitering af andenordensperspektivet.

\section{Efterspørgslen efter en andenordensdidaktik på læreruddannelsen}

Førnævnte Elaine Munthe efterspørger læreruddannernes kernekompetence eller, med henvisning til Shulman (2005), læreruddannelsens "signature pedagogy", som betegner professionsuddannelsens indretning og praksis, der tager sigte på kvalificeringen af de fremtidige professionsudøvere. Hun spørger: "Innen juss blir case brukt i utstrakt grad, innen medisin er det arbeidet i klinikken. Men hva ville det tilsvarende være innen lærerutdanning?" (Munthe \& Haug, 2010, s. 191).

Lunenberg et al. (2014) anfører det primære karakteristikum for læreruddannere som det at være teacher for teachers. Goodwin et al. (2014) angiver i forlængelse heraf det centrale som "...a deep understanding of what it means to teach about teaching." (Goodwin et al., s. 285). Men som nævnt tidligere er der et videnshul på dette felt. Forskningen hævder, at lærerud- 
dannere og læreruddannelsesdidaktik generelt er underbelyst: “...teacher educators are an underresearched and poorly understood occupational group" (Murray, 2005, s. 125). I deres artikel om, hvad en læreruddanner bør vide og kunne, anfører Oettingen \& Jensen (2017), at det er begrænset, hvad vi ved herom, og at man stiltiende går ud fra, at de kompetencer, der gælder for folkeskolelæreren, også kan overføres på læreruddannelsen, og at der "...så at sige ikke findes en særlig domænespecifik viden for fx "teacher educator". Undersøgelser om lærerstuderendes forståelse af læring og undervisning efterspørger samme forskningsviden (Beck et al., 2013; Korthagen et al., 2005). Goodwin et al. (2014) sammenfatter denne efterspørgsel i titlen på deres analyse af læreruddanneres vidensbasering: What forms of knowledge do teacher educators use that differ from those used by teachers in general...? De understreger som Oettingen \& Jensen, at det at blive læreruddanner ikke et en simpel totrinsproces fra lærer til læreruddanner, men at forskningen ikke desto mindre fokuserer minimalt på, hvad læreruddannere bør vide og kunne, og hvordan de kan udvikle denne viden og disse færdigheder.

Hoban (2004) betragter denne mangel på viden som en konsekvens af, at læreruddannelse betragtes på linje med læreres praksis, som en praksis, der ikke behøver specialisering, men hvor man - som lærerne i skolen ofte underviser, som man selv er blevet undervist i skolen eller på uddannelsen (Lortie, 1975; Krogh-Jespersen, 1993; Lindhart, 2007; Oettingen \& Jensen, 2017; Blume, 1971 i Lunenberg et al., 2007; Bayer \& Brinkkjær, 2003; Cochran-Smith \& Zeichner, 2005; Murray \& Male, 2005). Accepteres denne parallelisering af læreres og læreruddanneres praksis, skærpes behovet for, at undervisningen på uddannelsen er eksemplarisk og vidensbaseret.

Det langsigtede mål er, at de kommende lærere bliver i stand til at træffe reflekterede didaktiske valg og udvikle professionen og deres egen didaktiske praksis og ikke blot videreføre den undervisning, de selv er blevet præsenteret for (Munthe \& Haug, 2010). Lunenberg et al. (2007) undersøgte i et review og i casestudier læreruddannernes muligheder for at påvirke og ændre perspektiv og praksis hos kommende lærere. Undersøgelserne “... led to the conclusion that we have discovered what is almost a blank spot in both the body of knowledge on teacher education and the actual practices of many teacher educators." (Lunenberg et al., 2007, s. 586).

Som en følge af den begrænsede forskning i læreruddannelsesdidaktik generelt og i andenordensdidaktik specifikt bliver det påkrævet at komme tættere på en forståelse af, hvilken didaktisk viden læreruddannere kan betjene sig af og basere deres praksis på. Oettingen \& Jensen (2017) spørger, 
"hvordan læreruddannere formidler transformationen fra deres egen undervisning til den undervisning, de lærerstuderende skal praktisere? Hvordan bliver undervisningen på uddannelsen et eksempel for undervisningen i skolen?" Forfatternes svar herpå er second order teaching, der indebærer at gøre sine egne didaktiske valg til genstand for kritik med henblik på at vise og eksemplificere, hvorledes en given undervisning didaktiseres. (Oettingen \& Jensen, 2017, s. 31). Det er forskning om en sådan andenordensdidaktik, artiklen baseres på (Loughran \& Berry, 2005; Loughran, 1996; 2006; 2008; Lunenberg et al., 2014; Munthe \& Haug, 2010; Iskov, 2013; Sjöström, 2018; Lunenberg et al., 2007; Murray \& Male, 2005; Korthagen et al., 2005; Oettingen \& Jensen, 2017; White, 201; Goodwin et al., 2014; Goodwin \& Kosnik, 2013; Tingholm \& Papadopoulos, 2018; Davey, 2013).

Loughran når frem til, at a pedagogy of teacher education kan udvikles ved at fokusere på uddannelsens iboende dilemmaer og spændinger og eksplicitere disse i læreruddannelsens praksis:

\section{It is time for teacher educators to explicitly frame teacher education as being problematic in such a way as to illustrate that what they know, how they know it, why it matters and what it looks in practice is central to that which might be described as quality in teaching about teaching. (Loughran, 2008, s. 1181)}

Vejen til en sådan læreruddannelsesdidaktik tager i denne artikel afsæt i en heuristisk definition af andenordensdidaktik som: Planlægning, gennemførelse, analyse og udvikling af undervisning med kommende lareres undervisning for øje, der synliggør relevansen af egen undervisning for de kommende læreres undervisning.

Som Oettingen \& Jensen hævder, og som Loughran understreger, må andenordensdidaktikken indebære eksplicitering af undervisningens begrundelse, underviserens valg, den viden, der ligger bag, og tankerne om, hvordan den kommer til udtryk i selve undervisningen. Ved at vise og gøre læreruddannelsesdidaktikken eksplicit kan den bidrage til forståelse af sammenhænge mellem undervisningen på uddannelsen og i skolen og mellem den teoretiske viden og lærerens praksis. Uden en sådan refleksion over forholdet til undervisning i skolen er andenordensperspektivet fraværende, og kravene til undervisningen ikke anderledes end undervisning andre steder.

Det er artiklens ærinde i det følgende at efterkomme og operationalisere denne efterspørgsel gennem udviklingen af begrebet om modelling, 
en anvendelig andenordensdidaktisk model og anbefalinger vedrørende eksemplarisk undervisning.

\section{Modelling i andenordensdidaktisk praksis}

Lunenberg et al. (2007) når i deres undersøgelse af, hvordan kommende lærere kan overskride egne praksiserfaringer, frem til, at læreruddannernes egen undervisning, viden herom og formulering af undervisningens begrundelser og sammenhænge er centrale for at udvikle de studerendes viden om samme og deres kompetencer til begrebsbrugende og udviklingsbaseret lærerpraksis. Læreruddannelsens didaktiske praksis gøres derigennem til genstand for analyse med henblik på identifikation af andenordensdidaktisk eksemplaritet og potentiale. Lunenberg et al. bruger modelling som begreb herfor og læner sig op af en definition fra Gallimore \& Tarp (1992): "We define modelling by teacher educators as the practice of intentionally displaying certain teaching behaviour with the aim of promoting student teachers' professional learning" (Lunenberg et al. 2007, s. 589). På denne baggrund opererer de med to former for modelling, der i det følgende anvendes som analytiske kategorier for en udfoldelse af begrebet.

Implicit modelling henviser til, at læreruddannernes egen undervisning skal være eksemplarisk i forståelsen 'practice what you preach'. Med tanke på, at kommende lærere mimer den praksis, de selv har været udsat for, giver dette god mening, al den stund undervisningen har potentiale til at blive efterlignet i skolen. Artiklens pointe er dog ikke, at læreruddannere skal undervise 1:1 som lærere i skolen, men stille deres didaktiske valg til rådighed for eksemplificering.

Til forskel fra skolen, hvor eleverne skal lære gennem fagene, skal de lærerstuderende netop lære at undervise. Formålet er i skolen elevernes langsigtede bedste i forbindelse med dannelse og uddannelse, mens det på læreruddannelsen primært er kvalificering til varetagelse af lærerprofessionen og til videregående uddannelse. Både lovgivning, formål, mål, indhold og metoder er forskellige. Hvad der er alment både i skolen og på læreruddannelsen er derimod fordringen til didaktikken og undervisningen om, at de skal foranstalte læring og være afstemt således, at forholdet mellem indholdet, målet, metoderne i videst muligt omfang er tilpasset de lærendes forudsætninger (se fx Iskov, 2017b; Hiim \& Hippe, 1997; Jank \& Meyer, 2006; Klafki, 2016/1985 for sådanne almen didaktiske betragtninger). Implicit modelling henviser i forlængelse heraf til, at de didaktiske valg er illustra- 
tive for en afstemt didaktik derved, at der er intern sammenhæng mellem læreruddannerens begrundelser, de betingelser, der er for undervisningen, og underviserens didaktiske beslutninger.

Loughran \& Berry (2005) beskriver en udgave af modelling, som korresponderer med implicit modelling i denne betydning:

\section{...modelling is about us 'doing' in our practice that which we expect our students to do in their teaching. This means we must model the use of engaging and innovative teaching procedures for our students rather than deliver information about such practice... (Loughran \& Berry, 2005, s. 194)}

White (2011) tager dog forbehold for, at læreruddannerne ikke kan forudsætte, at de metakognitive aspekter af undervisningen er åbenlyse for de studerende, og Lunenberg et al. (2007) når i deres undersøgelse frem til, at denne form for modelling eller eksemplaritet har begrænset effekt, bl.a. fordi det kræver, at de studerende forstår og bliver bevidste om de didaktiske sammenhænge, potentialet heri og begrænsningerne samt de nødvendige oversættelser til deres egen didaktik i skolen.

Explicit modelling indebærer, at underviseren sætter ord på sammenhænge og afstemning af de underliggende begrundelser for undervisningen med de influerende betingelser og rammefaktorer som baggrund for didaktiske valg og beslutninger. I forlængelse heraf angiver Sjöström (2018), Lunenberg et al. (2007) og Tingholm \& Papadopoulos (2018) behovet for en didaktisk metakommunikation i læreruddannelsesregi. Dette beskrives som andenordensundervisning, der kobler underviserens hvad, hvordan og hvorfor med de studerendes metakognitive læreprocesser. Berry \& Loughran inkluderer desuden adgang til underviserens backstage: "At another level, there is also a need to offer our students acces to the pedagogical reasoning, feelings, thoughts and actions that accompany our practice..." (Loughran \& Berry, 2005, s. 194). Lunenberg et al. nævner Loughrans (1996) 'thinking aloud' som en vej til explicit modelling, der indebærer, at undervisningen indledes med begrundelserne for dens struktur. Derigennem kan underviseren demonstrere sin didaktiske tænkning om sammenhænge med forudgående undervisning, intentioner om den efterfølgende undervisning og forbindelserne herimellem, som handler om undervisningens kontinuitet og progression $i$ de studerendes læring. "According to Loughran, thinking aloud ties together 
- in the 'action present' - the thinking of the teacher educator, the pedagogy used and the students' learning." (Lunenberg et al., 2007, s. 591).

Eksplicitering af valg, sammenhænge, begrundelser og didaktisk refleksion gør det muligt for underviseren $\mathrm{i}$ et andenordensperspektiv at koble undervisningens teori og praksis:

\section{Good teacher educators are reflective in their own work, working at a meta-cognitive level in their own teaching by explaining their actions in words in relation to why and how they teach as they do. This is articulation of the tacit knowledge of teaching, as it is a way to bring tacit information to the awareness of the learners (...) and (thus) to bring practical experiences to a theoretical level (Smith, I Lunenberg et al, 2007, s. 592)}

Potentialet ved explicit modelling er, som White (2011) fremhæver i sit selvstudie, at ekspliciteringen også hjælper til at sætte ord på hendes tavse praksisviden og bliver en læreproces for såvel hende som de studerende, såfremt de har en responsiv relation og et dialogisk fællesskab. Loughran \& Berry (2005) redegør for, at de studerende via explicitering af de dilemmaer og spændinger, der er iboende i læreruddannelsesdidaktikken, kan hjælpes til en oversættelse af den teoretiske videns betydning for praksis. Oversættelsen fordrer involvering af de studerende i professional critique af læreruddannernes tilgang til undervisning og læring (Loughran \& Berry, 2005, s. 195). Oettingen \& Jensen (2017) peger også på, at læreruddannerne må gøre deres valg til genstand for kritik. Fremstilling af underviserens overbevisninger, overvejelser om og begrundelser for undervisningen stiller underviseren $\mathrm{i}$ en sårbar position, men White hævder, at hun blev mindre bekymret for ikke at undervise perfekt, i takt med at hun blev mere eksplicit om sine overvejelser. Igennem den forståelse, som dialogen om hendes undervisning bibragte, oplevede hun sig selv som mere og mere selvsikker.

Der hævdes således at være flere gevinster ved en sådan inddragelse af de studerende i dialog om og kritik af undervisningen. Inddragelsen vil også indbyde til samarbejde om undervisningen, involvere de studerende og kunne bidrage til, at de forholder sig aktivt til at varetage egen uddannelse og læring. En sådan forståelse af læreruddannelsens formål og funktion skriver sig ind i et personlighedsudviklende paradigme, der i en dansk/ nordisk sammenhæng giver plads til en forståelse af læreruddannelsen som en dannelsesinstitution (Lund, 2018; Andersson, 1995). 
Omtalte dialog og samarbejde har desuden potentiale som eksemplarisk (jf. implicit modelling) for det samarbejde, de kommende lærere selv skal indgå i. I den danske folkeskole er det bestemt ved lov, at lærerne skal samarbejde med forældrene om elevernes tilegnelse af kundskaber og færdigheder, ligesom lærerne er forpligtet på at samarbejde med eleverne og andet pædagogisk personale om deres undervisning - som derfor også vil blive genstand for dialog og udvikling (Folkeskoleloven § 1 og § 18, stk. 4).

Betydningen af eksplicitte begrundelser og af formulering af de didaktiske overvejelser og valg var også et fund i en mindre undersøgelse af lærerstuderendes opfattelse af undervisningen på to læreruddannelser i Danmark (Beck et al., 2013). Her fandt vi, at underviseren måtte sætte ord på sin videnanvendelse, sin didaktisk-teoretiske viden, for ad den vej at bidrage til de studerendes etablering af mening og læring, når begrundelser, koblinger til praksis, didaktiske valg og sammenhænge udfoldes. Dette blev sammenfattet $\mathrm{i}$ en artikel med den sigende titel: "Sig, hvad du tænker - og gør, hvad du siger" (Iskov, 2013), som var en opfordring til læreruddanneren om at eksemplificere og eksplicit modellere sin undervisning.

Efter således at have identificeret et behov for at udvikle en andenordensdidaktik til læreruddannelsen, at have indkredset forståelsen af, hvad denne drejer sig om, og de potentialer for didaktikken, der er ved implicit og eksplicit modelling, bliver ærindet i det følgende at bidrage til operationalisering af en sådan andenordensdidaktik. Dette gøres ved først at beskrive en almen didaktik for folkeskolen, som dernæst videreudvikles til en almen læreruddannelsesdidaktik, der gør det muligt at få øje for og nærmere konkretisere andenordensperspektivet. Præmissen er, at læreruddannelsesdidaktikken må hente sine begrundelser i forståelser af lærerprofessionen og reflektere skolens og lærerens didaktik for at kunne eksplicitere, hvordan den står i relation hertil. Beskrivelsen af den skoledidaktiske model og de teoretiske perspektiver, den er funderet på, udfoldes forholdsvist grundigt i det følgende, fordi disse sammen med præmisserne og logikken i modellen overføres til den andenordensdidaktiske model.

\section{En almen didaktisk model for grundskolen}

I et almen pædagogisk og empirisk ph.d.-projekt om læreres didaktiske intentionalitet (Iskov, 2017b) blev dette begreb omsat i en didaktisk tænkning, der integrerer læreres pædagogiske hensigter med deres opmærksomhed på omstændigheder og vilkår for deres didaktiske valg. Denne didaktik 
er siden udmøntet i en planlægnings- og analysemodel anvendelig for læreres undervisning (Iskov, 2018; Iskov \& Tange, 2018; Iskov, 2019; Duedahl et al., 2020).

Modellen udspringer af en forståelse af didaktik og undervisning, som har sit ophav i den almene pædagogik (Rokkjær, 1997; Oettingen, 2001; 2010; Komischke-Konnerup, 2018), der dermed også danner baggrund for præsentationen af den andenordensdidaktiske model. Dette perspektiv indebærer, at didaktikken altid må betragtes i relation til den konkrete pædagogiske praksis, der per definition er åben, uforudsigelig, modsætnings- og dilemmafyldt. På disse præmisser har læreren hensigter på elevernes vegne, der kommer til udtryk i undervisningens normativitet (Qvortrup \& Bengtsen, 2013; Iskov, 2017a). Didaktikken og omsætningen af hensigterne i konkrete undervisningshandlinger tilføjer dog et teknoidt element (Dale \& Krogh-Jespersen, 2004) til pædagogikken i form af en særlig didaktisk kausalitet, som altid må forstås inden for en ikke-teknologisk, men pædagogisk tænkning (Qvortrup \& Bengtsen, 2013).

Til systematisk og begrebslig tænkning herom betjener didaktikken sig traditionelt af modeller både til planlægning, gennemførelse, analyse og udvikling af undervisning (Uljens, 1997, i Sjöström, 2018). Modellen i figur 1 og dens tredelte systematik bidrager hertil ved at positionere læreren i pædagogisk praksis som handlende aktør, der baserer sine didaktiske valg på praktisk fornuft og ræsonnement gennem en afvejning af sine forudgående hensigter og begrundelser for undervisningen med de aktuelle vilkår og omstændigheder. ${ }^{1}$

1 Denne tilgang til lærerarbejdet, som er udfoldet i lærerforskningen (Fenstermacher \& Richardson, 1993; Smyth, 1989; 1991; Larsen, 2015), kan mødes med indvending om, at tendere en (for) rationalistisk og individualistisk udlægning af læreren og dennes didaktiske praksis. Samme kritik kan vendes mod Dales (1998) begreb om didaktisk rationalitet, som også er underliggende her. Placeringen af didaktikken og læreren i konkret pædagogisk praksis modsiger dog denne kritik. Det samme gør anvendelsen af modellen i en dialogisk kollaborativ praksis. I nærværende artikel danner modellen afsæt for udviklingen af en andenordensdidaktik til læreruddannelsen, som netop baseres på refleksion, kritik og dialog i et fællesskab mellem læreruddannere og studerende. 


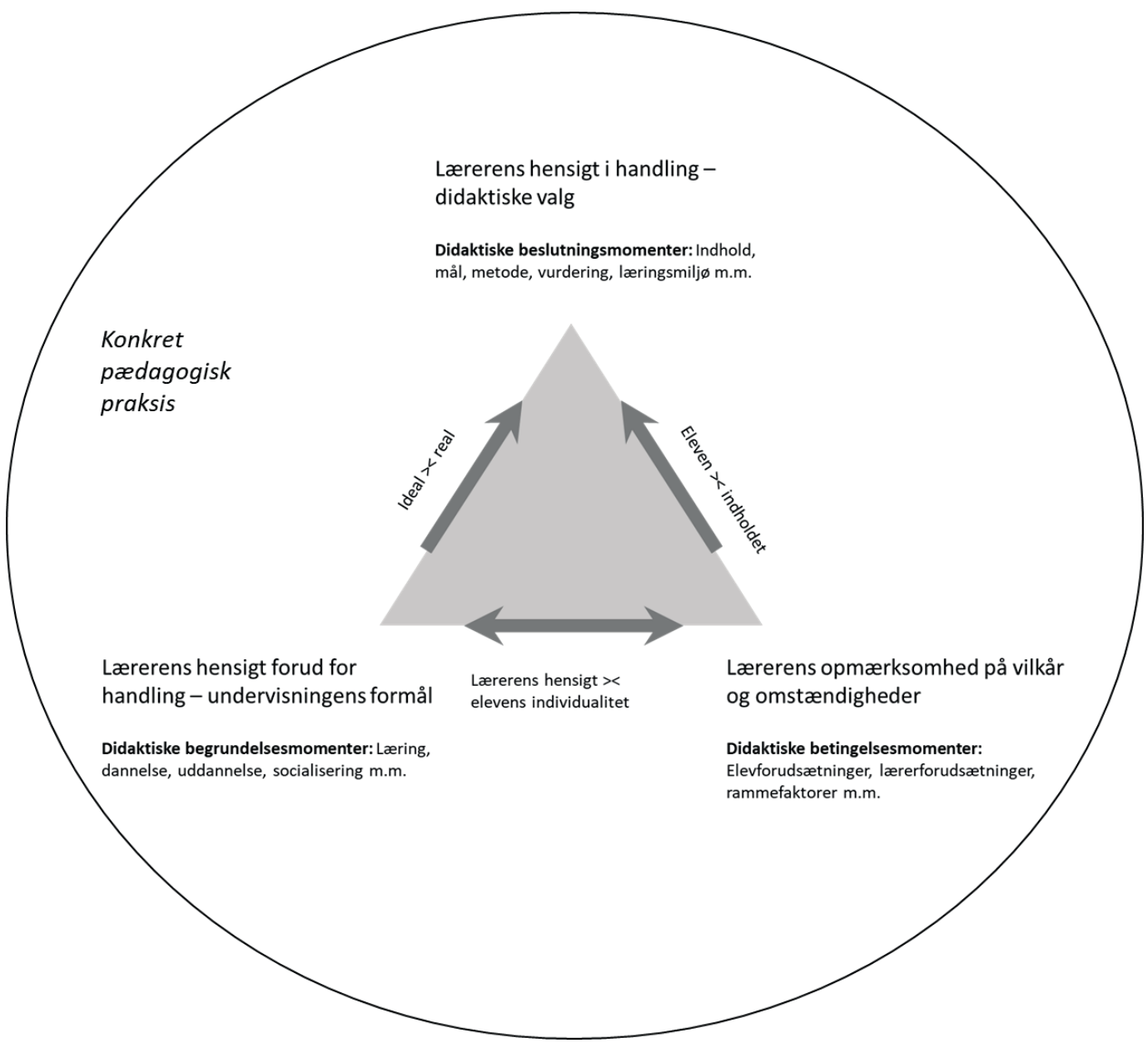

Figur 1. Almen didaktisk model for skolen.

De didaktiske kategorier i modellen er opdelt, alt efter om de refererer til:

- Lærerens hensigt forud for handling om læring og kontekstuafhængige værdier og normativitet udtrykt i undervisningens formål. Disse omsættes ikke nødvendigvis i reale beslutninger, men omfatter afsættet for planlægning og undervisning forud for dens gennemførelse, hvorved de får betydning som didaktiske begrundelseselementer, der danner afsæt for beslutningerne og må afstemmes med betingelserne.

- Lærerens opmærksomhed på vilkår og omstændigheder henviser til den sammenhæng, læreren, eleverne og undervisningen indgår i, og som er betingende for, hvad læreren meningsfuldt kan gøre. Det kan være faktorer i skolens fysiske, kulturelle, institutionelle og interpersonelle verden, forudsætninger ved læreren selv og elevforudsætningerne. Disse faktorer betegnes didaktiske betingelsesmomenter, og dem 
må læreren være opmærksom på at afstemme sine begrundelser og beslutninger med.

- Lærerens hensigt $i$ handling kommer til udtryk i de didaktiske valg af undervisningens indhold, mål, metode osv., der har karakter af didaktiske beslutningsmomenter, og som træffes på baggrund af en afstemning af de forudgående hensigter og begrundelsesmomenter med de didaktiske betingelsesmomenter.

Som nævnt er deten didaktisk pointe, at kategorierne må afstemmes ilærerens planlægning for at tilgodese konsistent undervisning med sammenhæng og samspil eksempelvis mellem dannelsesintentioner, elevforudsætninger og det, der foregår i undervisningen. Konsistent henviser her ikke til, at undervisningen skal være modsigelsesfri. Det kan den ikke være i en almen pædagogisk og didaktisk forståelsesramme, hvor undervisning tværtimod er kendetegnet af modsigelser, dilemmaer, antinomier og paradokser (Oettingen, 2010). Derfor er her tale om begrebet i en særlig betydning, der henviser til, at undervisningens modsætningsforhold i videst muligt omfang søges afstemt med henblik på sammenhænge mellem de forskellige didaktiske kategorier. Denne afstemning vedrører de almen pædagogiske grundproblemstillinger, der er udtrykt i modellens tre akser. Den pædagogiske grunddifference er indskrevet på den nederste akse som dilemma mellem lærerens hensigt og elevens individualitet. På aksen mellem lærerens forudgående hensigt og hensigten i handling, eller mellem begrundelser og beslutninger, figurerer spændingen mellem det intentionelle eller ideale og det reale som en genkommende didaktisk udfordring (Petersen \& Kvols, 2017), og på aksen mellem vilkår/betingelsesmomenter og didaktiske valg/beslutningsmomenter er indskrevet elevens møde med indholdet som den primære didaktiske difference i en almen pædagogisk praksis, hvor opgaven er åbningen af indholdets dannelsespotentiale.

Ovenfor er modellen illustreret som planlægningsmodel, hvorfor der er indlæst en rækkefølge, jf. læreren som handlende ud fra praktisk ræsonnement, og de pædagogiske grundproblemer, som læreren må overveje i den forbindelse. Modellen kan også anvendes som analysemodel til refleksion over og udvikling af praksis. I så fald bør alle tre pile være dobbeltpile for at illustrere de dialektiske forbindelser mellem de forskellige didaktiske kategorier og momenter, ligesom man kan forestille sig relationer mellem trekantens sider og modstående vinkler. 
Som redegjort for tidligere er modellens kategorier og systematik almen og gældende for såvel grundskolen som læreruddannelsen. De didaktiske kategorier er formalt set de samme i begge arenaer, men udfyldes og indholdsbestemmes de, vil de naturligvis repræsentere noget forskelligt i hhv. læreruddannelsen og skolen. Tredelingen og fordringen om en afstemning af kategorierne samt de dilemmaer, der udtrykkes via modellens akser, er derimod generisk. Også på læreruddannelsen er der et genkommende modsætningsforhold mellem underviserens hensigter ideelt set - og den realitet, der kommer til udtryk i praksis gennem didaktiske valg. Også her er det et didaktisk spørgsmål, hvordan de studerendes forudsætninger møder undervisningens indhold, ligesom der på læreruddannelsen er en potentiel difference mellem undervisningens formål og de studerendes individualitet.

En udfoldelse af ligheder og forskelle mellem kategorierne i de to arenaer falder uden for denne artikels rammer, men det er centralt at opholde sig ved begrundelsesniveauet. Som redegjort for implicerer modellen til grundskolen almen pædagogikken og dermed skolens dannelsesformål. Spørgsmålet er, om dette kan overføres til læreruddannelsen, der først og fremmest har professionsudøvelse som sit formål. Trods det at læreruddannelsen som en professionsbacheloruddannelse har udfaset dannelse som formål (Rømer, 2019), er almen dannelse dog fortsat en del af indholdet på læreruddannelsen (ufm.dk). Ikke bare som indhold og noget, de studerende skal have viden om, men også som formål i kraft af de kommende læreres opgave med at bidrage til elevernes dannelse i skolen. Betragtes læreruddannelse inden for det personlighedsudviklende paradigme (Lund, 2018; Andersson, 1995), træder de studerendes dannelse tydeligt frem, og dermed også de pædagogiske paradokser og didaktiske dilemmaer forbundet hermed. Dette er argumentet for, at ovenstående almen pædagogiske tænkning og model kan perspektiveres til og anvendes i regi af læreruddannelsen i en dansk/nordisk tradition.

Modellen potentialiseres og indskrives i det følgende afsnit i en andenordensdidaktik for læreruddannelsen. Denne består grundlæggende i overvejelser over ligheder og forskelle mellem de to arenaer og en omsætning af disse refleksioner i didaktiske valg, der tager højde herfor. Den andenordensdidaktiske model inviterer til sådanne overvejelser og indbyder til refleksion over, hvordan de didaktiske kategorier, dilemmaer og didaktiske beslutninger i skolen har betydning for læreruddannelsesdidaktikken. Gennem systematiserede refleksioner herom er det pointen, at andenordensdidaktikken bliver mulig at eksplicitere i sin udfoldelse. 


\section{En andenordensdidaktisk planlægnings- og analysemodel}

Den inderste cirkel i figur 2 repræsenterer skolens didaktiske praksis, som er læreruddannelsens overordnede sigte og indhold. Den omgivende trekant illustrerer læreruddannelsesdidaktikken, der bør kendetegnes af samme konsistens, hvorfor de didaktiske kategorier og akserne i den yderste trekant også bør afstemmes i planlægning af undervisning på læreruddannelsen (implicit modelling).

Andenordensperspektivet kommer til syne i refleksionsrummet mellem de to trekanter (de stiplede pile), som giver plads til overvejelser om og artikulation af forholdet mellem de to trekanter, mellem skolens og læreruddannelsens didaktik (explicit modelling).

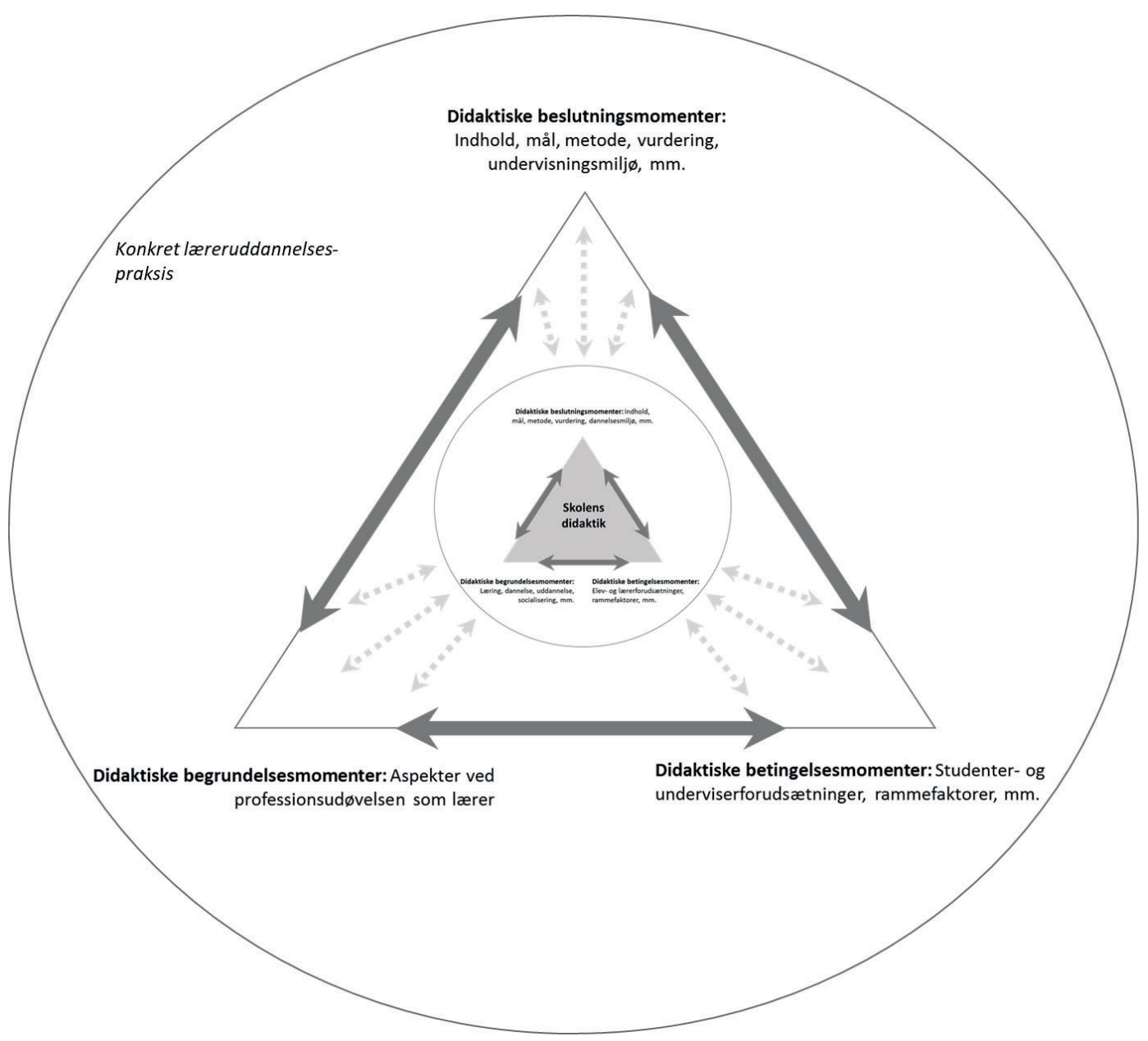

Figur 2. Andenordensdidaktisk model til læreruddannelsen. 
Modellen hviler på samme grundlag og logik som udfoldet i afsnittet om skolens didaktik, hvorfor nærværende afsnit fokuserer på andenordensperspektivet og potentialet for implicit og explicit modelling.

Vender vi tilbage til den heuristiske definition af andenordensdidaktikken, var det centrale planlægning, gennemførelse, analyse og udvikling af undervisning med de kommende læreres undervisning for øje og synliggørelse af forbindelserne herimellem. Det betyder, at læreruddannelsesdidaktikken må baseres på indgående viden om skolens og lærerens didaktik, hvorfor betingelser, begrundelser og beslutninger på læreruddannelsesniveau må tænkes i relation hertil (de stiplede pile).

Overvejelserne om de forskellige didaktiske kategorier i læreruddannelsen kan være relevante for forskellige og andre kategorier og sammenhænge i den inderste trekant. Pointen er, at forbindelserne mellem de didaktiske kategorier i de to trekanter og arenaer er vilkårlige. Figurativt må man derfor forestille sig, at den inderste trekant kan vende anderledes end den yderste.

Modellen bør altså ikke læses sådan, at der kun er en direkte forbindelse mellem de to trekanters vinkler og parallelle akser. Det er ikke nødvendigvis sådan, at læreruddannerens didaktiske beslutninger kun er relevant for de kommende læreres overvejelser over samme. Indholdet i undervisningen på læreruddannelsen kan fx tænkes at være vigtigt for lærernes kompetence til at begrunde undervisningen eller tilpasse den til betingelsesmomenter i form af elevforudsætninger. Omvendt kan det være tilfældet, at kategorierne i læreruddannelsen er relevante for samme kategorier i skolens didaktik. Fx kan man uden videre forestille sig, at hensigten med og begrundelserne for undervisningen på læreruddannelsen er relevante for de kommende læreres begrundelser for undervisningen i skolen, eller at indholdsvalget på læreruddannelsen er relevant for indholdsvalget i skolen.

Også den andenordensdidaktiske model kan anvendes både som planlægnings- og analysemodel. Anvendt som planlæaningsmodel, må underviseren afstemme begrundelser, betingelser og beslutninger i sin egen undervisning (akserne i den yderste trekant) ved at tage afsæt $\mathrm{i}$ hensigten med undervisningen, afstemme denne med de betingende faktorer som grundlag for at træffe didaktiske valg. I tillæg dertil må underviseren i andenordensdidaktisk perspektiv overveje, hvordan undervisningen på læreruddannelsen står i relation til undervisningen i skolen (rummet mellem de to trekanter) og træffe didaktiske valg afledt heraf. 
Anvendt som analyse- og refleksionsmodel kan modellen åbne for en undersøgelse af, hvorvidt undervisningen er konsistent og internt afstemt, og hvorvidt det andenordensdidaktiske perspektiv er medtænkt på hvilken måde.

\section{Modelling og eksemplarisk undervisning på læreruddannelsen}

Modellen bidrager til andenordensdidaktikken, derved at den kan anvendes til operationalisering af implicit og explicit modelling som forskellige former for og konkrete bud på eksemplarisk undervisning. Ærindet i dette sidste afsnit er at sammenfatte og konkretisere en sådan didaktisk praksis på læreruddannelsen i tre forskellige betydninger af eksemplarisk undervisning:

1. En undervisning, der er eksemplarisk i den forstand, at der er konsistens og samspil mellem læreruddannerens didaktiske begrundelser, betingelser og beslutninger i udførelsen (implicit modelling)

2. En undervisning, hvor underviseren med henvisning til teori udfolder og ekspliciterer, hvordan den er eksemplarisk ved at være internt afstemt (explixit modelling A)

3. En undervisning, hvor underviseren med henvisning til teori udfolder og ekspliciterer, hvordan den er eksemplarisk og relevant for den kommende lærers undervisning i skolen (explicit modelling B).

De tre nævnte former er ment som formale bidrag til et analytisk og didaktisk udviklende blik i læreruddannelsen og søger at svare på Lunenberg et al.'s spørgsmål: "The question that now presents itself is how this situation can be improved, in order to ensure that modelling is given its rightful place within teacher education" (Lunenberg et al., 2007, s. 598). ${ }^{2}$ Kompleksiteten og fordringen om refleksivitet øges igennem de tre udgaver af eksemplarisk undervisning derved, at de forrige udgaver indeholdes i de næste.

2 De tre niveauer er inspireret af Lunenberg et al. (2007), der via empiriske studier identificerer implicit modelling og tre former for explicit modelling, hvor underviseren 1) ekspliciterer sine valg, 2) ekspliciterer sine valg og deres relevans for undervisning i skolen og 3) ekspliciterer sine valg og forbinder disse til almen teori. Disse tre er slået sammen til to i min udlægning, der begge involverer henvisninger til teori, fordi ærindet ikke er at beskrive, hvad lærere gør, men at udvikle teori og anbefalinger om forskellige måder at didaktisere og undervise eksemplarisk på. 


\section{Ad 1: Eksemplarisk undervisning som implicit modelling}

Denne udgave søger at leve op til sloganet "Teach as you preach" (Loughran, 1996; Lunenberg et al., 2007). Ikke på en måde, der kan overføres til skolen 1:1, fordi der som redegjort tidligere er kategorisk forskel på læreruddannelse og skole. Det eksemplariske består her i konsistent didaktik med en intern sammenhæng mellem formål og begrundelser for undervisningen, der er afstemt med de aktuelle betingelser, herunder de lærerstuderendes forudsætninger, og underviserens tilpassede didaktiske beslutninger om indhold, mål og metoder mv. Det betyder med andre ord, at det primært er den yderste trekant i modellen ovenfor, som underviseren anvender til at planlægge og betragte sin undervisning igennem. Ved at afstemme og overveje samspillet mellem de forskellige didaktiske kategorier og de iboende dilemmaer herimellem kan didaktikken komme til syne for de lærerstuderende som veltilrettelagt, hvorved undervisningen bliver forbilledlig og underviseren rollemodel for de studerendes (mester)læring i situerede erfaringer med konsistent undervisning. Den eksemplariske værdi hviler på forudsætningen om, at den inderste trekant som almendidaktisk model accepteres som model for konsistent og velbegrundet undervisning i skolen, og at det samme bør kendetegne undervisningen på læreruddannelsen.

Jævnfør de tidligere nævnte begrænsninger ved implicit modelling (White, 2011; Lunenberg et al., 2007) er det dog ikke tilstrækkeligt, at læreruddannelsesdidaktikken er internt afstemt. Dette må også synliggøres og ekspliciteres.

\section{Ad 2: Eksemplarisk undervisning som explicit modelling $A$}

Ved at sætte ord på sammenhængene rundt i den yderste trekant om de didaktiske begrundelser og beslutninger bag undervisningen, som den fremtræder for de studerende og underviseren, bliver viden, der ellers kunne være virksom som tavs praksisviden, bevidstgjort også for underviseren. Eksplicitering af, hvordan undervisningen er internt afstemt og hvorfor på denne måde, fremkalder underviserens viden om fag, didaktik og læreprocesser, men også om lovgivning og det formål, som undervisningen tager afsæt i. Dette ved 'thinking aloud' (Loughran, 1996), som bl.a. kan udmøntes ved i indlede undervisningen med begrun- 
delserne herfor. Ekspliciteringen kan dog ikke altid planlægges på forhånd, den teoretiske viden ikke blot videregives, den må fortolkes, situeres og bringes i spil med den specifikke didaktiske praksis. Viden om rammefaktorer, differentiering og tilpasning af indhold og metoder til de studerendes forudsætninger kan gøres eksplicit. Dertil bliver det relevant for underviseren at formulere sig med selvindsigt om sine egne forudsætninger, overbevisninger, forståelser og ressourcer i forhold til den konkrete undervisning. Den eksemplariske værdi består i, at de studerende får adgang til underviserens didaktiske tænkning, begrebsbrugende og udviklingsorienteret didaktisk praksis med mulighed for, hvad White (2011, s. 487) kalder "learning to think like a teacher".

At gøre undervisningen og de didaktiske valg eksplicitte og forbinde praksis med teoretisk viden og begreber er udfordrende (og ifølge Lunenberg et al. (2007) ikke udbredt blandt læreruddannere). At udvide ekspliciteringen til også at omfatte forbindelserne mellem læreruddannelsesdidaktik og skoledidaktik må formodes at udfordre yderligere. Ikke desto mindre er det netop artikulationen af forbindelserne mellem de to arenaer, mellem modellens to trekanter, der udgør andenordensperspektivet, og som er omdrejningspunktet i det følgende.

\section{Ad 3: Eksemplarisk undervisning som explicit modelling $B$}

Denne form for eksemplarisk undervisning implicerer de to foregående og aktualiserer i tillæg til ovennævnte teoretiske viden professionsteori, viden om teori-praksis-forbindelser, om lærerprofessionalitet, professions- og uddannelsesforståelse, sammenhænge mellem professions-, uddannelses- og forskningsviden, læreruddannelsesforskning osv. Her er det i tillæg til de to foregående udgaver op til underviseren at gøre klart, hvordan læreruddannelsesdidaktikken forbinder sig til didaktikken i skolen ved at udfolde korrespondensen herimellem. De studerende har behov for hjælp til at oversætte læreruddannelsesdidaktikken til deres egen skoledidaktik, til at bygge bro mellem oplevelser, erfaringer og læring på læreruddannelsen og skolens didaktik (og det er ikke meningen, at de skal eftergøre den - modelling skal ikke kopieres til skolens arena). Der er risiko for en teknisk transfertænkning, som underviseren må medtænke og tale imod, om 
end det i sidste ende er op til de studerende at forbinde undervisningen til deres egen udvikling og oversætte den viden, de tilegner sig om forholdet mellem de to trekanter, til deres egen didaktiske praksis. Dette som fjern transfer (Wahlgren, 2013), hvor det tilegnede potentielt ændres i relation til den studerendes kontekst for undervisning, og hvor anvendelsesværdien er afhængig af, at den studerende kan se formålet med at oversætte og omsætte det lærte i egen praksis.

Modellen kan give blik for de komplekse forbindelser mellem uddannelsesdidaktikken og skolens didaktik, hvis man som underviser spørger sig selv om, hvilke forbindelser der er. Besvarelsen af sådanne spørgsmål og ekspliciteringen heraf indebærer, at underviseren må blive bevidst og formulere sig om, hvilken uddannelses- og professionsforståelse der er i spil, og hvordan underviseren opfatter sammenhængen mellem disse, som den kommer til udtryk i den konkrete undervisning. Det indebærer forklaringer af, hvordan uddannelsens og undervisningens organisering, indhold og form er professionsrettet.

Indledningsvis blev spørgsmålet stillet: Hvordan kan man bidrage med andenordensdidaktiske refleksioner i forhold til det særlige aspekt i læreruddannelsesdidaktik, som handler om at se, koble og tydeliggøre undervisningen på læreruddannelsen $i$ sammenhæng med undervisningens planlægning, gennemførelse og udvikling $i$ skolens arena?

Den andenordensdidaktiske model kan finde anvendelse til såvel planlægning som analyse af en eksemplarisk læreruddannelsesdidaktisk praksis, der søger at afstemme didaktiske betingelser, begrundelser og beslutninger. Ved at udpege et refleksionsrum mellem de to arenaer giver modellen desuden anledning til en didaktisk tænkning, der også eksplicit forholder sig til sammenhænge herimellem. Sammenfattende er det er måske værd at påminde om, at modellens inderste trekant repræsenterer formålet og indholdet i læreruddannelsesdidaktikken, som den yderste trekant, læreruddannelsesdidaktikken, beskæftiger og forbinder sig med varierende aspekter af. Eksplicitering af andenordensdidaktikken (jf. explicit modelling $B$ ) består som en følge heraf i 1) formulering af den afstemte didaktik jf. den yderste trekants kategorier og 2) formulering af, hvordan denne forbinder sig til de kommende læreres didaktik jf. den inderste trekants kategorier. 
Som det er fremgået, inviterer andenordensdidaktikken til dialog mellem underviser og studerende om didaktikken, undervisningen og relevansen for skoledidaktikken. Eksemplarisk undervisning i den tredje udgave kan hjælpe til, at underviserens tavse viden bevidstgøres og bliver eksplicit som baggrund for udvikling af didaktikken - med potentiale for læring og en oplevelse af meningsfuldhed i undervisningen hos de studerende, ved at de kan se koblingsmuligheder til deres forestående praksis i skolen.

Det er antageligt sårbart at lægge sin didaktik frem, og det kræver øvelse, erfaringer og tryghed. Ligeledes kræver det udstrakt refleksivitet hos underviseren, hvis denne i et andenordensperspektiv skal kunne forholde sig til sin forholden sig og drage nytte heraf i udviklingen af didaktikken. Eksperimenterende og undersøgende samarbejde kunne måske konceptualiseres og bidrage til andenordensrefleksion med afsæt i artiklens modeller og anbefalinger. Men dette kalder på en anden artikel om kollaborativ didaktisk udvikling blandt læreruddannere.

\section{Referencer}

Andersson, C. (1995). Läras för skolan eller skolas att lära - tankemodeller i lärarutbildning. Uppsala Studies in Education nr. 63. Doktorafhandling. Uppsala University Publications.

Bayer, M., \& Brinkkjær, U. (2003). Professionslæring i praksis. Danmarks Pædagogiske Universitetsforlag.

Beck, M., Iskov, T., \& Frederiksen, L.L. (2013). Undervisning i læreruddannelsen - et oplæg til grundlagsdrøftelser. VIA SYSTIME.

Cochran-Smith, M., \& Zeichner, K. (2005). Studying teacher education: The report of the AREA Panel on Research and Teacher Education. Erlbaum Press. https://doi.org/10.5860/choice.432338

Dale, E.L. (1998). Pædagogik og professionalitet. Forlaget Klim.

Dale, E.L., \& Krogh-Jespersen, K. (red.)(2004). Uddannelse og Dannelse - læsestykker til pædagogisk filosofi. Forlaget Klim.

Davey, R. (2013). The professional identity of teacher educators - Career on the cusp? Routledge. https://doi.org/10.4324/9780203584934

Duedahl, T.V., Iskov, T., \& Tange, N. (2020). Dannelse i pædagogisk praksis. Forskningsprojekt $i$ samarbejde med Odder kommune. Forskningsrapport. VIA UC.

Fenstermacher, G., \& Richardson, V. (1993). The elicitation and reconstruction of practical arguments in teaching. Journal of Curriculum Studies, 25, 101-114. https://doi. org/10.1080/0022027930250201

Folkeskoleloven. https://www.uvm.dk/folkeskolen/folkeskolens-maal-love-og-regler/ om-folkeskolen-og-folkeskolens-formaal/folkeskolens-formaal

Gallimore, R., \& Tharp, R. (1992). Teaching mind in society: Teaching, schooling, and literate discourse. I: Mol, L.C. (red.), Vygotsky and education: Instructional implications and applications of sociohistorical psychology (s. 175-205). Cambridge University Press. 
Grant, M.J., \& Booth, A. (2009). A typology of reviews: An analysis of 14 review types and associated methodologies. Health Information and Libraries Journal, 26(2), 91-108. https:// doi.org/10.1111/j.1471-1842.2009.00848.x

Goodwin, A.L., \& Kosnik, C. (2013). Quality teacher educators = quality teachers. Conceptualizing essential domains of knowledge for those who teach teachers. Teacher development, 17 (3), 334-346. https://doi.org/10.1080/13664530.2013.813766

Goodwin, A.L., Smith, L., Souto-Manning, M., Cheruvu, R., Ying Tan, M., Reed, R., \& Taveres, L. (2014). What should teacher educators know and be able to do? Journal of Teacher Education, 65(4), 284-302. https://doi.org/10.1177/0022487114535266

Hedegaard, K.M., Kvols, A.M., \& Petersen, B.V. (red.)(2017). Pædagogik og lærerfaglighed. Forlaget Klim.

Hiim, E., \& Hippe, H. (1997). Læring gennem oplevelse, forståelse og handling. Gyldendal Undervisning.

Hermansen, M., Jensen, E., og Krejsler, J. (2005). Didaktikken og individet - når senmoderne elever skal lære. Alinea

Imsen, G. (2004). Lærerens verden - indføring i almen didaktik. Gyldendals Lærerbibliotek.

Iskov, T. (2013). Sig, hvad du tænker - og gør, hvad du siger! I: Beck, M.H., Iskov, T., og Frederiksen, L.L. (red.), Undervisning i læreruddannelsen - et oplæg til grundlagsdrøftelser. VIA SYSTIME.

Iskov, T. (2017a). Lærerens didaktiske intentionalitet. I: Hedegaard, K.M., Kvols, A.M., \& Petersen, B.V. (red.), Pædagogik og lærerfaglighed. Forlaget Klim.

Iskov, T. (2017b). Didaktisk intentionalitet. Mod en udvidelse af den analytiske didaktik mellem policy og praksis. Aarhus University, Faculty of Arts.

Iskov, T. (2018). Lærerens målkundskab. I: Laursen, P.F. (red.), Mål med mening. Hans Reitzels Forlag.

Iskov, T. (2019). Planlægning af undervisning med elevernes dannelse for øje. Emu.dk https:// emu.dk/grundskole/paedagogik-og-didaktik/didaktiske-tilgange/thomas-iskov-planlaegning-af-undervisning-med

Iskov, T., \& Tange, N. (2018). Dannelsesmål i skolen. I: Laursen, P. F. (red.), Mål med mening. Hans Reitzels Forlag.

Jank, W., \& Meyer, H. (2006). Didaktiske modeller. Gyldendals Lærerbibliotek.

Klafki, W. (1985/2016). Dannelsesteori og didaktik-nye studier (3. udg.). Forlaget Klim.

Komischke-Konnerup, L. (2018). Gentagelsens pædagogik. Ph.d.-afhandling. Aalborg Universitet.

Korthagen, F., Loughran, J., \& Lunenberg, M. (2005). Teaching teachers - studies into the expertise of teacher educators: an introduction to this theme issue. Teaching and teacher education, 21, 107-115. https://doi.org/10.1016/j.tate.2004.12.007

Krogh-Jespersen, K. (1993). Læreruddannelsesdidaktik. I: Schnack, K. (red.), Læreruddannelsesdidaktik 3. Serien Didaktiske studier. Danmarks Lærerhøjskole.

Larsen, L. L. (2015). Lærerens verden. Almendidaktiske refleksioner over klasserumserfaringer. Aarhus University, Faculty of Arts.

Lindhart, L. (2007). Hvor lærer en lærer at være lærer? Læring som deltagelse i vekslende handlesammenhænge. Books on Demand.

Lortie, D.C. (1975). Schoolteacher. A sociological study. The University of Chicago Press.

Loughran, J. (1996). Practicing what I preach: modelling reflection to student-teachers. Research in Science Education, 25(4), 431-451. https://doi.org/10.1007/bf02357386

Loughran, J. (2006). Developing reflective practice: Learning about teaching and learning through modelling. Falmer Press. https://doi.org/10.4324/9780203453995

Loughran, J. (2008). Toward a better understanding of teaching and learning about teaching. I: Cochran-Smith, M., Feiman-Nemser, S., \& McIntyre, J. (red.), Handbook of research 
on teacher education: Enduring questions in changing contexts (3. udg., s. 1177-1182). Routledge. https://doi.org/10.1111/j.1467-873x.2008.00421.x

Loughran, J. (2011). On becoming a teacher educator. Journal of Education for Teaching, 37(3), 279-291. https://doi.org/10.1080/02607476.2011.588016

Loughran, J., \& Berry, A. (2005). Modelling by teacher educators. Teaching and teacher education, 21, 193-203. https://doi.org/10.1016/j.tate.2004.12.005

Lund, J. (2018). Uddannelsesforståelser i læreruddannelsen - belyst gennem litteraturstudier og empiriske undersøgelser blandt undervisere. Studier i læreruddannelse og -profession, 3(1), 3-31. https://doi.org/10.7146/lup.v3i1.97264

Lunenberg, M., Korthagen, F., \& Swennen, A. (2007). The teacher educator as a role model. Teaching and teacher education, 23, 586-601.

Lunenberg, M., Dengerink, J., \& Korthagen, F. (2014). The professional Teacher Educator. Sense Publishers.

Munthe, E., \& Haug, P. (2010). En integrert, profesjonsrettet og forskningsbasert grunnskolelærerutdaning. Norsk Pedagogisk tidsskrift, 94(3), 188-202.

Murray, J., \& Male, T. (2005). Becoming a teacher educator: evidence from the field. Teaching and teacher education, 21, 125-142. https://doi.org/10.1016/j.tate.2004.12.006

Møller, F. (2011). Kampen om evalueringen. Læreres perspektiver på konkurrerende evalueringsparadigmer. Syddansk Universitet.

Oettingen, A. v. (2001). Det pædagogiske paradoks - et grundstudie i almen pædagogik. Forlaget Klim.

Oettingen, A.v. (2010). Almen pædagogik. Gyldendals Lærerbibliotek.

Oettingen, A.v., \& Jensen, E. (2017). Hvad skal en læreruddanner vide og kunne for at uddanne lærere? Paideia, Tidsskrift for professionel pædagogisk praksis, 13.

Qvortrup, A. (red.) (2019). Formålsdrevet uddannelse og undervisning. Dafolo.

Qvortrup, A., \& Bengtsen, S.S.E. (2013). Didaktiske teorier og didaktikkens nerve. I: Qvortrup, A., \& Wiberg, M. (red.), Læringsteori og didaktik. Hans Reitzels Forlag.

Qvortrup, A., \& Wiberg, M. (2013). Læringsteori og didaktik. Hans Reitzels Forlag.

Rokkjær, Å. (1997). Pædagogik: et personligt anliggende. Semi-forlaget.

Shulman, L.S. (1986). Paradigms and research programs in the study of teaching: a contemporary perspective. I: Wittrock, M.C. (red.), Handbook of research in teaching (s. 3-36). Macmillan.

Smyth, J. (1989). Developing and sustaining critical reflection in teacher education. Journal of teacher education, 2(40), 2-9. https://doi.org/10.1177/002248718904000202

Smyth, J. (1991). Problematising Teaching Through a "Critical" Approach to Clinical supervision. Curriculum Inquiry, 21(3), 321-352. https://doi.org/10.1080/03626784.1991.11075373

Rømer, T. (2019). FAQ om dannelse. Hans Reitzels Forlag

Schnack, K. (1994). Didaktik og/eller curriculum. Uddannelse, 27(2), 64-68.

Schnack, K. (1999). Er didaktik og curriculum det samme? http://pure.au.dk/portal/files/120/ Er_didaktik_og_curriculum_det_samme.pdf

Schou, L.R. (2016). Den nye folkeskolelov i spændingsfeltet mellem to dannelsestraditioner. Undervisningens indhold, 36(1), 4655.

Sjöström, J. (2018). Didaktik i integrative lärarprofessionsämnen. Studier i læreruddannelse og -profession, 3(1). https://doi.org/10.7146/lup.v3i1.97571

Tingholm, H.B., \& Papadopoulos, P.M. (2018). Udvikling af metakommunikation i undervisningen på videregående uddannelser. I: Qvortrup, A. (red.), Formålsdrevet uddannelse og undervisning. Dafolo.

Ufm.dk. https://ufm.dk/aktuelt/pressemeddelelser/2018/forligskredsen-vil-styrke-dannelse-i-laereruddannelsen

Uljens, M. (red.)(1997). Didaktik - teori, reflektion och praktik. Lund: Studentlitteratur. 
Iskov: Læreruddannelsens andenordensdidaktik

Wahlgren, B. (2013). Transfer i VEU. Tolv faktorer der sikrer, at man anvender det, man lærer. Nationalt center for kompetenceudvikling, DPU, Aarhus Universitet.

Westbury, I., Hopman, S., \& Riquarts, K. (2000). Teaching as a reflective practice. The German Didaktik Tradition. Routledge. https://doi.org/10.4324/9780203357781

White, E. (2011). Working towards explicit modelling: experiences of a new teacher educator. Professional Development in Education, 37(4), 483-497. https://doi.org/10.1080/19415257 .2010 .531628 